\title{
Brazilian responses to violence and new forms of mediation: the case of the Grupo Cultural AfroReggae and the experience of the project "Youth and the Police"
}

\author{
Respostas brasileiras à violência e novas mediações: \\ o caso do Grupo Cultural AfroReggae e a experiência \\ do projeto "Juventude e Polícia"
}

1 Centro de Estudos de Segurança e Cidadania da Universidade Candido Mendes.

Rua da Assembléia 10, sala 810, Centro, 20011-901, Rio de Janeiro RJ. sramos@candidomendes. edu.br

\begin{abstract}
This article discusses some aspects of the Brazilian response to urban violence, focusing both official public safety policies and actions of the civil society. The text identifies the lack of a national public safety policy, indicates successful governmental experiences carried out in some states and municipalities, and concentrates on the actions of the police. Analyzing the responses of the civil society, the paper is emphasizing the campaign for disarming the population and the role played by the media. It shows the appearance of groups of young people living in the favelas, organized in turn of cultural experiences that, in multiple aspects, are characterized as "new mediators" in society. These groups thematize violence and try to build new stereotypes dissociating them from the image of criminality. The article describes in particular the cases of the Grupo Cultural AfroReggae, of Rio de Janeiro, and the pilot experience carried out in collaboration with the Minas Gerais Military Police, called "Youth and the Police". The AfroReggae group is a typical example of such a "new mediator", and the initiative of carrying out a work in cooperation with the police opens new perspectives for the traditionally scarce participation of civil organizations engaged in public safety in cooperative projects with the police.
\end{abstract}

Key words Violence, Youth, Civil society, Social movements, Favelas
Resumo O artigo discute aspectos das respostas brasileiras à violência urbana, focalizando tanto políticas governamentais de segurança pública como ações da sociedade civil. Identifica a inexistência de uma política nacional de segurança pública, indica experiências governamentais bemsucedidas em estados e municípios e focaliza a atuação das polícias. Ao analisar as respostas da sociedade civil, destaca a experiência da campanha do desarmamento e o papel da mídia. O trabalho situa o surgimento de grupos de jovens de favelas organizados em torno de experiências culturais que, em vários aspectos, caracterizam-se como "novos mediadores" na sociedade. Esses grupos tematizam a violência e procuram construir novos estereótipos que dissociem os jovens de periferia das imagens de criminalidade. $O$ artigo descreve em particular o caso do Grupo Cultural AfroReggae, do Rio de Janeiro, e a experiência-piloto em batalhões da Polícia Militar de Minas Gerais, o projeto "Juventude e Polícia". Argumenta-se que o Grupo AfroReggae é tipicamente um novo mediador, e que a iniciativa de realizar um projeto com a polícia abre novas perspectivas no campo da reduzida tradição participativa de organizações da sociedade civil na esfera segurança pública e em projetos de cooperação com a polícia.

Palavras-chave Violência, Juventude, Sociedade civil, Movimentos sociais, Favelas 


\section{Introduction}

The Brazilian homicide rates figure among the highest in the world. At the core of the problem - be it as victims, be it as authors of violence - are the young, especially the poor and black young living in favelas and suburbs. The responses of the State and the Brazilian civil society to the problem of criminality and violence are slow and unsatisfactory. In the 90 s however, a number of cities witnessed the appearance of artistic and cultural initiatives led by young people living in favelas and in the outskirts of the urban areas. Although heterogeneous and not articulated with one another, these experiences are becoming increasingly important through creating cultures of peace in opposition to the dynamics of urban conflicts.

This article aims to discuss aspects of the Brazilian response to urban violence, focusing governmental public safety policies as well as actions of the civil society. Among different responses, we will observe the appearance of groups, which in several aspects are characterized as new social "mediators". Particular reference will be made to the case of the Grupo Cultural AfroReggae of Rio de Janeiro and to a pilot experience carried out in cooperation with the Center for Studies on Safety and Citizenship (Centro de Estudos de Segurança e Cidadania - CESeC) in battalions of the Minas Gerais Military Police, the project called "Youth and the Police". The AfroReggae group will be introduced as a typical new mediator and it will be shown that the initiative of carrying out a cooperative project with the police forces, besides being radically new, opens new perspectives for a stronger participation of organizations of the civil society in the field of public safety and for cooperation projects with the police.

\section{The criminal justice system, public safety policies and the police}

The homicide rates due to external causes in the great urban centers in Brazil figure among the highest in the continent, a trend verified since the 80 s and increasingly accentuated in the 90 s $^{1}$. Since 2003, Brazil surpassed the number of 50 thousand homicides per year. The victims of intentional lethal violence are mainly young black men, and residents of favelas and poor neighborhoods of the great urban centers2.

What public safety policies the country used for facing the increasing urban violence? During the more than 20 years since the beginning of the transition process following the military dictatorship (1985), the sector that made less progress with respect to modernization and democratization was the criminal justice system, in particular the police institutions ${ }^{3}$. Only since the mid-nineties we register the first systematic efforts for elaborating public safety policies based on a contemporary perspective of combining efficiency with human rights. Before that, the greater part of governments had relegated the issue to the corporative spheres of the police forces 4,5 . During the $80 \mathrm{~s}$ and part of the $90 \mathrm{~s}$, the increase of lethal violence was kept in silence by a great part of intellectual sectors, the media and even by nongovernmental organizations. As a matter of fact, rare exceptions apart, research centers for investigating issues related to violence focused on public safety are very recent creations in the academic and university environment.

The socioeconomic profile of the principal victims of lethal violence and their inability to exert public pressure explain in part the late awakening of governments, the media and the Brazilian civil society with regard to the topic public safety and to the need of investing in modernization, control and democratization of the police institutions. Most of the civil and military police forces in the different States of the Federation suffered a degradation process, and some of them became violent and inefficient. The organized crime centered on drugs and arms traffic corrupted wide segments of the police corporations, using mechanisms on different levels, which in some cases reach from the very bases up to the leadership 6 . In some States the violence of the police became a problem for the corporation itself, besides victimizing the poor populations that find themselves cooped up between the violence of drug-related crime warfare and a violent and corrupt police.

In the State of Rio de Janeiro, according to data of the Secretariat of Public Safety for the year 2005, the police was responsible for $14.2 \%$ of intentional violent deaths. The "resistance reports", shall say, the registries of deaths resulting from confrontations with the police, rose $280 \%$ in six years (from 289 in 1999 to 1,089 in 2005), demonstrating an outstanding 
increase in lethal violence practiced by the police. Like the homicide rates in the city, police violence assumes a specific geography as well. It is strongly concentrated in the western zone and in the suburbs, the poorer neighborhoods of the city. In 2003, the police battalions in the suburbs of Rio de Janeiro (3rd, 9th, 16th and 22nd Military Police Battalions) killed 501 civilians while the battalions in the southern zone (2nd, 19th, 23rd and 31st) killed 202. The lack of organizations engaged with civil rights in these areas together with the idea that deaths of civilians are a "natural" consequence of conflicts in favelas may explain these frightening numbers in some regions.

The phenomenon of abuse of lethal force by the police is a serious problem in different States of the Federation. Many police forces do not even publish statistical data about deaths occurred in action. In the States of São Paulo and Minas Gerais, where data are available, policies for reducing lethal police violence are being put in practice. In São Paulo, the number of deaths occurred in confrontations with the police decreased significantly: from 573 in 2004 to 300 in 2005 (www.ssp.sp.gov.br). In Minas Gerais, there was only a small decrease: from 103 in 2004 to 99 in 2005 (data from the Minas Gerais Military Police).

The characteristics of the deaths occurred in these confrontations indicate their dynamics. A detailed study of the "resistance reports" of the city of Rio de Janeiro focusing the years 1993 to 19967 revealed that the major part of victims were young males ( 15 to 29 years, with emphasis to the age group between 20 and 24 years), and that $64 \%$ of them were black, compared to the presence of $39 \%$ of black people in the population of Rio de Janeiro. The study also evidenced that the deaths resulting from police actions were concentrated in the favelas, that almost half of the victims had received four or more shots and that $65 \%$ of the dead bodies had received at least one shot in the back or in the head, indicating summary executions. The fact is that, in Rio de Janeiro, police violence is out of the control of the higher commands. To the extent "license to kill" was given to the policemen operating in favelas and poor neighborhoods, a wide field was opened for corruption and for the so-called "adjustments" between drug dealers and police agents 8 .

With regard to safety policies, some important experiences were made. Recently, some municipalities passed to involve researchers and organizations of the civil society in the elaboration and implantation of public safety policies 9 . The case of Diadema (SP), where the rates of homicides, robberies and thefts could be considerably reduced through integrated police actions, controls in bars and programs directed to the young population is the most emblematic one, because through these actions a stigmatized region of the metropolitan area of São Paulo was transformed into a model, today being copied by many towns and cities in the country10.

On State government level, although the actions for controlling violence continue strongly repressive, some important initiatives for modernizing the police were taken. The most successful is the case of Minas Gerais: since a few years ago, the Military Police maintains a cooperation agreement with the Study Center for Criminality and Public Safety (Centro de Estudos de Criminalidade e Segurança Pública - CRISP) for monitoring criminal activities. In 2005, the Secretariat for Social Defense created the Institute for Public Safety Management, in charge of integrating the police forces and organisms of the criminal justice system (Department of Justice, children's courts, penitentiary system, etc.). Following the example of the CompStat of New York (www. nypd.gov), the commanders responsible for the different areas meet once a month for sharing reports on successful tactics and establishing new goals to be met.

On national level, during the presidential election process in 2002, the Workers Party (Partido dos Trabalhadores) supported the elaboration of a National Safety Program, counting on the cooperation and participation of experts from different States. For the first time, the country could count on a program whose proposal was combining social and preventive aspects, the police and repressive policies and control and modernization of the police forces.

After more than three years since the beginning of Lula da Silva government however, only a very small part of the proposals were put into practice, and the National Safety Program was virtually abandoned. The National Secretariat for Public Safety, created during the government of Fernando Henrique, operates today with even less resources than under the previous government. While, in 2005, the National Fund for Public Safety counted on approximately R \$ 170 million for investments in the 
entire country, the budget for public safety of the Sate of São Paulo alone amounted to R\$ 6 billion.

A planning and implementation of integrated public safety actions will mainly depend on the pressure society is able to exert upon the three governmental spheres, making them recognize the urgency of the themes violence and public safety. With only a few exceptions, the governmental responses to the phenomenon of violence in the first years of this new century notwithstanding the political party at stake still seem to be characterized by their being slow and poor to respond the present level of violence. The idea of violence being "natural" prevails widely and is favored by the incapacity of its main victims, the marginalized populations, to raise their voices. Despite the important experiences in some States of the Federation, police institutions that did not make the transition from protection of the State - their role under the military dictatorship - to protection of the citizens, especially the poor ones, who many times are dealt with as if they were enemies, still predominate in the country ${ }^{3}$. There is not one single directive on national level that could be called a national public safety policy.

\section{The Disarmament Statute and the role of the media}

In 2003, the civil society made, among others, an important step towards reducing the deaths caused by firearms. Under the leadership of nongovernmental organizations that mobilized great public manifestations, through articulations with members of the House of Representatives engaged with peace policies and supported by an important part of the media, the Federal Senate promulgated the Disarmament Statute, which sets forth a series of provisions for the control and possession of firearms and forbids carrying arms. Thousands of arms were collected in the course of this unprecedented national campaign in favor of peace (according to the Sou da Paz Institute, 439 thousand firearms were handed over in 2005). In October 2005, people were asked in a national referendum if they agreed that the commerce of firearms should be prohibited in the entire national territory. The answer of the majority was "no". In spite of the negative result of this stage of the implementation of the Statute, the fact that organizations of the civil society began to elaborate a "safety policy", that the issue had called the attention of the media and that the Statute had been approved by the Congress, can be considered paradigmatic for the control of violence in Brazil.

Here we must emphasize the important role the media played in the promotion of public safety policies and in the control of the police forces ${ }^{11}$. Despite the still remaining problems, during the last years the leading newspapers of the country made deep-reaching modifications in their coverage of crime and violence and the stereotype of the "police reporter" was changed significantly. In the great newspapers, the reporters covering crimes and public safety issues are no more typical "police reporters" but seek increasingly to hear sources other than the police in their investigative reports.

\section{Young people of favelas and suburbs: new mediators}

In the context of civil responses to violence one recently observes an important mobilization process of young people living in favelas and suburbs. There appear projects or local programs based on cultural or artistic activities, frequently developed and coordinated by the young people themselves. Examples for these initiatives are the groups Olodum and Timbalada, of Salvador, AfroReggae, Nós do Morro, Cia. Étnica de Dança and Central Única de Favelas, of Rio de Janeiro, besides hundreds of small groups organized around the hip-hop culture, in the outskirts of São Paulo, Porto Alegre, Belo Horizonte, Recife, Brasília and São Luís.

These groups express the ideas and perspectives of the young people of the favelas through different languages such as music, theater, dance and cinema. At the same time, they seek to produce alternative images to the stereotypes of criminality associated with this segment of the society, and try to keep the young away from drug-related crime by seducing them with the glamour of the arts, visibility and success. In general, these groups and projects are characterized by four aspects that innovate the repertory of principles of the entities engaged with human rights, nongovernmental organizations (NGOs) and of the left, where the initiatives of the Brazilian civil society traditionally take place: 
1) They are market-oriented and, to the contrary of the traditional NGOs, search for alternative sources of income and employment, besides trying to professionalize their members and to introduce them to the labor market. In this sense, they are the opposite of the "nonprofit" culture that characterizes the Brazilian NGOs ${ }^{12}$. Some of these groups operate simultaneously with two juridical bodies, a NGO (for receiving donations from national and international foundations) and a "production company" (for making contracts for shows, CDs or films). Although claiming to belong to the field of "social work", some of these groups are increasingly seeking to become independent from international donations, sustaining themselves as cultural enterprises disputing the market.

2) They invest strongly in individual careers and life histories, valuing the symbolic field of subjectivity and fostering the formation of artists and leaders, whose success passes to serve as example. In counteraction to the creation of stereotypes, they seek to create powerful images of young people of the favela who, against all expectations, became filmmakers, stage actors or musicians. In other words, in these groups the media, success and fame are understood as ingredients of political militancy. They use insistently the media and seek for partnerships with the great communication corporations, appearing not only as artists, but also as leaders talking in the name of the young people from the favelas. In this sense, they are different from the syndicalistic and associative model of the left, where the "collective" prevails over individualistic deviations.

3) They are strongly linked to their territory, to the point that frequently the names of the groups, the texts of their songs, the T-shirts and clothes they use make reference to the name of their community of origin (Vigário Geral, Vidigal, Cidade de Deus, Pelourinho, Candeal, Alto Vera Cruz, Alto do Pina, etc.). Surprisingly, the intense and repeatedly affirmed territorial commitment is not translated into parochialism or nationalism. Their "love for the community" goes hand in hand with open adherence to the signs of globalization (Coca-Cola, Nike, etc.) and the connection between their place and the universe is established through the Internet, sites and journals. High priority is given to interchange with other communities (including with young people of the middle class) and to trips in the country and abroad.
4) The texts of their songs, their clothes, the names of their groups (AfroReggae, Ethnic Company, Conscientious Union of the Black, Brother Brown, etc.) are pronouncedly antiracist and show strong commitment with the black race. Not necessarily making part of the so-called "black movement", these young people refer in their music and in interviews permanently to the fact of being "black" and to living in favelas. Their negritude and the fact of belonging to the periphery are mixed up in an interesting formula combining complaint and proud (racial and territorial), many times expressed in sung and danced explosions of joy, as occurs in the groups Olodum, Timbalada and AfroReggae. This brings them into an opposite position to the silence predominating in traditional cultural expressions like Samba with respect to racial discrimination, and also differs from the traditional protests against racism based on the idea of victimization used by the black movement. "Self-esteem" and "attitude" are the terms in the native language that best define the new image associated with the young black people of the favelas.

Together with the creation of "local NGOs", a phenomenon identified by analysts of the favelas ${ }^{13}$, these projects and initiatives - heterogeneous and without a link between each other - are becoming important not only as poles for the construction of an alternative culture to drug traffic, but as "mediators"; in other words, as translators between the young of the favelas and governments, the media, universities and, many times, international actors, like foundations and cooperation agencies. They are the bridge connecting a fractured world, the city and the favelas. Many times, they represent the only point of contact for those who want to understand what is going on with the young living in the poor neighborhoods of the city.

As refers to violence and crime, the greater part of these groups are maintaining a state of equilibrium, on one hand, denouncing police violence; and, on the other hand, trying to keep independent of the despotism of armed factions of drug-related crime. Some of them try to play the role of mediators in the "wars" between different factions of drug-related crime, and assume openly the mission of "preventing young people from involving in drugs traffic" $8,14,15$, but this is not necessarily the rule. The group Nós do Morro (We from the Hillside), of Rio de Janeiro, for example, refus- 
es to discuss narcotics traffic, and the objectives of the group do not involve any commitment with regard to creating alternatives to criminal activity (www.nosdomorro.com.br). Other initiatives show a quite ambiguous position as refers to the "world of crime". This is the case of the hip-hop groups, on one hand identifying themselves with the "pals" in jail and, on the other hand, complaining about the stereotype of criminality being associated with the young black people of the poor neighborhoods.

It must be pointed out that these initiatives - identified as new forms of mediation in the responses to violence - are not the only ones nor are they necessarily the most efficient for "keeping young people away from drug dealing". Numberless religious groups, especially of Pentecostal orientation, dedicate themselves today to converting young people who engaged in criminal activities. "Football schools" and sports programs for fighting idleness, discovering talents and creating professional alternatives are proliferating in favelas and poor neighborhoods. Countless governmental and private programs promote cultural activities such as dance, circus, music and theater, with the intent to offer recreation and to professionalize adolescents. The specific characteristics of the new mediators are: the groups are led by the young people of the favelas themselves and construct a discourse in the first person; they are able to express spells with which the young of the favelas can identify and create models, refuting their traditional images; they create new metaphors based on life histories; they are able of transiting in the media and in the community, among different social classes and governments. In other words: they transit between the local and the universal.

However, these young mediators must not be taken as examples for a contemporaneous spirit in syntony with the values of modernity. Their groups are heterogeneous but predominantly masculine. The practices and discursive constructions of many of these groups and of the hip-hop culture show evident traits of misogyny and homophobia 8,16 .

\section{The AfroReggae Group}

The Cultural Group AfroReggae is a nongovernmental organization created in 1993, whose basis is the favela called Vigário Geral, in Rio de Janeiro. The group was created following the killing of 21 innocent residents of the favela Vigário Geral in an illegal action of the police, result of an unsuccessful "agreement" between members of the police force and drug dealers, having to do with the usual weekly bribe. The purpose of the group is to offer cultural and artistic education to young residents of the favela, to enable them to construct their life as citizens, escape from narcotics traffic and underemployment, and act as multipliers for other young people. The main activity developed by the group is promotion of workshops in the fields of percussion, theater, circus, capoeira, video and informatics in the favelas Vigário Geral, Parada de Lucas, Cantagalo, Ramos, and Complexo do Alemão. Since its creation, the group founded a professional music band (AfroReggae Band) as well as eight other groups presenting themselves in shows (www.afroreggae.org.br). The AfroReggae Band presents itself in great shows in Brazil and abroad and enjoys visibility in the media, appearing frequently on television. The organization acquired great experience in working with children and adolescents of low-income families but their language reaches young people of other social classes as well. In parallel to the nongovernmental organization, the AfroReggae Group created a production company making money with shows and public presentations and employing young people in the different fields of artistic production. This production company sustains the actions of the nongovernmental organization together with the resources coming from international donations (Ford Foundation, Kellogg Foundation, HP Foundation, Avina, and others), national agreements with municipal authorities, ministries and State governments, and sponsors (TV Globo, Petrobrás, and others). The AfroReggae Group is typically a new mediator, seeking to approximate the favela and the middle class, operating in both directions. With the project "Urban Connections", for example (concerts in favelas presenting successful artists and groups), the AfroReggae brings musicians and famous bands to the favela, at the same time, "introducing" the favela to the artists and guests of the shows (public administrators, professionals from the media, businessmen, intellectuals, foreign visitors, etc.). Thus, the group uses the dimensions market and community, concentrating its efforts to territorial and racial affirmation of the favela and con- 
structing a discourse in the first person in the name of the young of the peripheries.

There are countless risks in a trajectory like this: the risk of being co-opted by the State or the sponsor groups, of being instrumentalized as "culture in the service of society" and the risk of new stereotypes being created, showing well-behaved black boys, that supposedly "escaped from delinquency", playing percussion instruments 17,18 . One of the facts that indicate that the group seems to be aware of some of these risks is its refuse to multiply their core centers for operating on large scale. The group understands that its role is not to substitute the State in generating alternatives for young people of the lower classes, and declares to be acting in the symbolic field, by creating and promoting models and pilots ${ }^{16}$. As refers to their music, the group avoids the well-behaved style and seeks for solutions of its own. The anthropologist Hermano Vianna (CD Nova cara, www. afroreggae.org.br) defines the music of the AfroReggae band as follows: The afroreggae multi-style is the product of an encounter of some of the most vital manifestations that recently appeared in the Brazilian music: mangue beat; rap paulistano; samba-reggae baiano; funk carioca. Here and there the echoes of Jamaican reaggae translated to "Rappa", of hip-hop transformed by Planet Hemp, the beat of xaxado and techno or the rhythmic percussion of capoeira and candomblé.

With respect to the factions of drug-related crime that dominate the favelas of Rio de Janeiro, the group seeks for a position of independence, a fact that allowed them to organize shows in communities ruled by different commands, despite of coming from a favela occupied by a faction, for more than 25 years in war with the faction of the neighbor favela, Parada de Lucas. They may be cultural activists but they are very concerned with presenting themselves as mature artists. They know they would have to surrender in a highly competitive market if they continued as "young people from social projects". This is why they employ all efforts for building themselves as professional artists.

\section{The Project Youth and the Police}

In 2002, the AfroReggae band produced a video clip for the music "Tô bolado" (a music telling the story of the killing in Vigário Geral), showing successive scenes of police violence in an open manifestation of the AfroReggae Group against the police. In the same year, one of the founding members of the group was hit by a gunshot in a police operation commanded by the BOPE (Battalion for Special Operations of the Rio de Janeiro Military Police) in the favela Vigário Geral. Almost all young people connected to AfroReggae have already been subject to situations of violence, corruption and humiliation on the part of the police, composing a vast repertoire of hatred and resentment, a copious "antipolice" culture in the group. In the end of 2002, the coordination of the group very surprisingly contacted the Center for Studies on Public Safety and Citizenship (CESeC) of the University Candido Mendes, expressing their wish to develop a project with the Police (not against the Police like one would expect). A project for "cultural invasion" of battalions of the police was submitted to the Ford Foundation and approved immediately. Negotiations with the Military Police of Rio de Janeiro, however, failed after months of attempts, and the proposal could not be put into practice in this State. In 2004, AfroReggae and the $\mathrm{CESeC}$ received an invitation from the Department for Social Defense and the Military Police of Minas Gerais for developing the project in the police battalions of the State capital, Belo Horizonte.

Initially this pilot project was developed in four stages, trying to establish a dialogue between the culture of the young and the police culture, and reducing the distance between the two groups through music and artistic activities. Workshops on percussion, theater, graffiti, dance and shows were organized in two battalions of Belo Horizonte. Approximately 70 police officers from each unit (each battalion counts on an effective of about 800 men) participated in these activities. The instructors of the workshops were young members of the AfroReggae group, including the artist who had been shot by the police in 2002, and the percussionist of the band, who had his tympanum perforated in an enforcement of the police. The surprising results of the first four weeks (one week per month) illustrated the importance of an original instrument for integrating the police and the young. The impact of the actions in this first stage of the project in the police and in the media showed the feasibility of valuing the human, ludic and artistic aspect of police officers - on the example this was done with young people - and, at the same 
time, reducing the prejudice of the police against the residents of favelas and suburbs.

In 2005, the Military Police of Minas Gerais considered the results of the actions in the first year so positive that it was decided to continue the partnership. AfroReggae and $\mathrm{CESeC}$ were invited to give lessons to policemen, who passed to work permanently with young people from the favelas of Belo Horizonte, organizing workshops on percussion, graffiti, dance, basketball and theater. A documentary film, Minas police, was produced under the direction of a professional, Estevão Ciavatta. In 2006, the government of Minas Gerais signed an agreement with AfroReggae and CESeC for continuing the project.

In January 2006, after an exhibition of the documentary at the headquarters of the Military Police of Rio de Janeiro, the Secretary for Security of this State recognized the positive effects of the proposal in Belo Horizonte and requested its implantation in police battalions in Rio de Janeiro. A first dialogue was established and negotiations are in course for verifying the feasibility of the project and the format that would fit best into the local reality.

Among the significant aspects of the experience, in comparison to the traditional forms of building awareness in the police forces (courses, meetings and lectures on human rights), we emphasize the following key elements:

1) The experience not only mobilized the good sense but also the hearts, minds and specially the bodies, in music, theater, graffiti, and other workshops. One must bear in mind that the traditionally "defensive" position of the corporation hampers most attempts to teach human rights by means of critical argumentation.

2) The essence of the intervention is not to "change the police officer" by teaching him intellectually something he - apparently - does not want to learn or resists to accept, but to propose new experiences for the police and for the young, who for the first time enter a police department. The young instructors with their "attitude" of the young people of the favela are making an experience that mobilizes their stereotype of the police; at the same time, they are provoking in the policemen the sense of rhythm and plasticity. The essence lies in the interchange between the young and the police without mediators (professors of human rights). The policemen and the young discover quickly that they are sharing much more identities that they had suspected. Besides discovering their frequently common origin and cultural proximity, both (the young people from the favela on one side and the police on the other) are groups stigmatized by the society and thus share the experience of being discriminated. The two groups, after establishing ties, surprised each other and felt protagonists of a new moment in the eyes of society.

3) Sound and image are crucial. The idea is to question the image society and the young have from the police and the image police and society have from the young black people from the favelas. Police "is image": the uniform, the weapon, the military esthetics, and the characterized vehicle. On the other hand, AfroReggae "is image": the artists, the shows, and the image of the favela and of the young. All stages of the project were filmed, photographed and registered in audio. Two experiences revealed important: the video workshops and the photo sessions. In these meetings the policemen saw themselves the way they were seen by the lens of the cameraman and discussed the "effects" these images produced in "the others" (other policemen and society). Like in a mirror game, they reconstructed their self-images, by seeing themselves being seen.

4) Coverage by the media is essential. The reports in the newspapers, in the radio and on television stimulated discussions, laughter and emotions. After the activities, the instructors repeatedly sat down in a circle for reading and discussing the subject under study. All this contributed to creating a new scheme we/they: "we", the participants of the project "Youth and the Police", and "they", the society and the media observing a police officer in a very uncommon situation. This we/they quickly substituted the first we/they: "we", the police, "they", AfroReggae. A group of policemen were trained and presented themselves in the beginning of 2005 with the AfroReggae band in a television program with great audience. After this, the group appeared repeatedly in public. This helped promoting the project, not only in $\mathrm{Mi}$ nas Gerais but also in other States.

5) In 2005, during the weeks in which the policemen (after a four weeks training in their Departments) went into the favelas for offering percussion, graffiti, basketball and dancing lessons, the dynamics of amazement-surpriseintegration between the two groups became even more intense. One of the techniques used 
was the "game of the truth". The young and the policemen set down in a circle and had very tense conversations about the experiences of the young with the police and the experiences of the police in patrols inside the favelas. The questions and complaints (the dialogue started with "What have you always wanted to know about the police") invariably began with the issue of how the police approach the population. The "stop and frisk" is always perceived as humiliating by the young black from the favelas 2 . Again, the direct contacts without mediators seemed to be the formula allowing a new therapeutic and curative logic of the type "truth and reconciliation" to arise. In these dynamics, the policemen discovered that admitting and recognizing the existence of the racial, social and geographic biases in the police practices was the first step towards communication. Once the "truth" was accepted,"reconciliation" turned possible. The rest was done by the magic of music and arts. The result of this "pedagogy of the drum" was the creation of new images and relationships.

Among the problems and limitations of the project is its difficult replication by other cultural groups in other States. The emotional and symbolic force incorporated by the AfroReggae Group (born out of a killing in a police action) is responsible for a good part of the impact produced in the first approximations with the police. The possibility of permanently mobilizing the media and creating the logic of the mirror, which is essential in the project, are also difficult to be reproduced by local cultural groups in other States. Finally, a problem created by the success of the project and by its visibility in the communication media is the resistance of important sectors of the police. Researchers from CESeC are evaluating the impacts of the project using focal groups, interviews and surveys. First results indicate that a considerable part of commanders and even simple "cops" think that "it is not the role of the police to appear on TV playing the drum" (the results of the evaluation will be published in 2007). In other words, we are talking about a polemic project, whose purpose is precisely to provoke surprise and to transform the traditional images of the police. To the extent these goals are met, the opposition against these changes (and the methods used for achieving them) will grow. In 2006, the command of the police force of the capital of Minas Gerais intends to institutionalize the project "Youth and the Police" as a regular program.

On national level, there obviously are still enormous barriers to overcome. The first one is persuading the commanders of the police to recognize that the barriers between young people and the police are something affecting the society as a whole. The second is to convince them that initiatives in which young people are given the opportunity to meet in the first person with police officers through music and artistic activities are powerful instruments for creating a modern and democratic police.

\section{Final considerations}

Given the scarce governmental investment in the police and the weak participation of organizations of the civil society in experiences focusing public safety issues, in recent years the groups of young people of the favelas - thematizing urban and police violence and seeking to produce alternative images to the stereotype of criminality - became a most vital part in the responses to violence. Against all expectations and prophecies to the contrary (revenge and hatred against the police corporation), the AfroReggae Group, created in response to a killing of civilians by the police and a typical translator in the relations between the young of the favela and the formal city, was able to use its own history as a symbol for developing a pioneer cooperation with the police. With the project "Youth and the Police", they created a very specific experience underlining the irreplaceable role of the young of the favelas in the construction of a new relationship between the police and society.

Part of the tragic scenario of violence as principal victims and principal protagonists, the young people of the favelas will necessarily play a decisive role in the efforts towards a reduction of violence. Some of these new groups of mediators seem to indicate that creative responses to a field with only small participative tradition of civil entities can work. New efforts of this kind should not be neglected by those who want to accompany the "ways out" the Brazilian society will produce, in the course of this decade, for facing violence and for constructing ways leading to safety, justice and citizenship. 


\section{References}

1. Souza ER, Minayo MCS, Silva CMFP, Reis AC, Malaquias JV, Veiga JPC, et al. Análise temporal da mortalidade por causas externas no Brasil: décadas de 80 e 90. In: Minayo MCS, Souza ER, organizadores. Violência sob o olhar da saúde: a infrapolítica da contemporaneidade brasileira. Rio de Janeiro: Ed. Fiocruz; 2003.

2. Ramos S, Musumeci L. Elemento suspeito: abordagem policial e discriminação na cidade do Rio de Janeiro. Rio de Janeiro: Civilização Brasileira; 2005.

3. Leeds E. Rio de Janeiro. In: Koonings K, Dirk K, editors. Fractured cities: social exclusion, urban violence and contested spaces in Latin America. London: Verso. [In print].

4. Soares LE. Meu casaco de general: quinhentos dias no front da segurança pública do Rio de Janeiro. São Paulo: Companhia das Letras; 2000.

5. Minayo MCS, Souza ER, organizadores. Missão investigar: entre o ideal e a realidade de ser policial. Rio de Janeiro: Garamond; 2003.

6. Lemgruber J, Musumeci L, Cano I. Quem vigia os vigias? Rio de Janeiro: Record; 2003.

7. Cano I. Letalidade da ação policial no Rio de Janeiro. Rio de Janeiro: Iser; 1997.

8. Soares LE, Bill MV, Athayde C. Cabeça de porco. Rio de Janeiro: Objetiva; 2005.

9. Sento-Sé JT, organizador. Prevenção da violência: o papel das cidades. Rio de Janeiro: Civilização Brasileira, 2005.
10. Guindani M. A criação de um novo paradigma em Diadema. In: Sento-Sé JT, organizador. Prevenção da violência: o papel das cidades. Rio de Janeiro: Civilização Brasileira; 2005. p. 117-145.

11. Ramos S, Paiva A. Mídia e violência: como os jornais retratam a violência e a segurança pública no Brasil. Boletim Segurança e Cidadania 2005; 9:1-16.

12. Landim L, organizador. Sem fins lucrativos: as organizações não-governamentais no Brasil. Rio de Janeiro: Iser; 1988.

13. Pandolfi D, Grynzspan M, organizadores. A favela fala. Rio de Janeiro: FGV; 2003.

14. Neat P, Platt D. Culture is our weapon: AfroReggae in the favelas of Rio. London: Latin America Bureau; 2006.

15. Bill MV, Athayde C. Falcão: meninos do tráfico. Rio de Janeiro: Objetiva; 2006.

16. Júnior J. Da favela para o mundo: a história do Grupo Cultural AfroReggae. Rio de Janeiro: Aeroplano; 2003.

17. Yúdice G. A conveniência da cultura: usos da cultura na era global. Belo Horizonte: Ed. UFMG; 2004.

18. Ochoa AM. Entre los deseos y los derechos: un ensaio crítico sobre políticas culturales. Bogotá: Instituto Colombiano de Antropología e Historia; 2003.

Article presented in 24/03/2006

Approved in 4/04/2006

Final version presented in 11/04/2006 